\title{
PUBLIC ADMINISTRATION IN THE FIELD OF LAND USE AND PROTECTION AND STATE LAND POLICY IN UKRAINE: PROBLEMS OF CORRELATION
}

\author{
Oleksandr Bondar ${ }^{1}$ \\ Zaporizhzhia National University, Ukraine
}

\begin{abstract}
The purpose of the paper is to study the problems of functioning and improvement of the organizational and legal mechanism of public administration in the field of land use and protection in Ukraine in their correlation with the issues of formation and implementation of the land policy of the state. Methodology. The essence of the problem under investigation is the lack of consistency in the implementation of land reform in Ukraine since its independence, which negatively affects the effectiveness and stability of the organizational and legal mechanism of public administration in the field of land use and protection. It, in turn, requires a detailed analysis of existing approaches to the formation and implementation of state land policy as an ideological and organizational basis for the development of the land system in the country. Analysis of recent researches and papers. Issues of legal ground for land reform in Ukraine, public administration in the land field were developed by a range of researchers, including, among others, Volodymyr Andreitsev, Pavlo Kulynych, Anatolii Miroshnychenko, Volodymyr Nosik, Vitalii Semchyk, Mykhailo Shulha, and others. At the same time, the degree of investigation of legal problems of the formation and implementation of state land policy, their interrelation with the issues of modernization of the management system in this area is still insufficient. Results. The state of legal ground for the development of state land policy and its correlation with the ecological, economic, and social policy of the state were analysed. The emphasis is on state target programs as an important economic-legal instrument of public administration in the land sector. The state of the institutional support of control and supervisory activities concerning the use and protection of land is examined. The conclusion on the necessity of the elaboration of an integrated regulatory legal act, which should consolidate key aspects of state policy in the land sector, is made. Value/originality. The analysis of the institutional support of control and supervisory activities in the land sector provides grounds to argue that this activity should be considered as an important element of the organizational and legal mechanism for ensuring sustainable development, and the reform of the system of the relevant authorities should not weaken the potential of this important function of public administration.
\end{abstract}

Key words: public administration, land resources, land use, land protection, state land policy.

JEL Classification: K1, K11, K32

\section{Introduction}

One of the key vectors of the transformation of the land system in Ukraine, which has begun since its independence, is a fundamental modernization of the system of public administration in the field of land use and protection. The Decree of the President of Ukraine dated May 30, 2001 No. 372/2001 "On the Main Directions of Land Reform in Ukraine for 2001-2005", among the priority areas of state policy in the field of land relations regulation, indicates, in particular, enhancement of the efficiency of state administration by land resources, improvement of land monitoring, management of state land cadastre and land

Corresponding author:

${ }^{1}$ Department of Civil Law, Zaporizhzhia National University.

E-mail: bondar.znu@gmail.com evaluation, betterment of the control over arrangement over land use and protection (the Decree of the President of Ukraine, 2001). This is entirely right approach, as the latest land reform in the state cannot be reduced only to a change in the system of land ownership relations, putting aside the issue of effective land management in order to ensure sustainable use and effective protection of these natural resources.

In this context, there is a suitable definition of Prof. Volodymyr Andreitsev for land reform as "the system of actions, which are regulated by special land legislation, of various subjects and a set of organizational, economic, environmental, scientific-technical, land management, 
and state-legal tools, aimed at radical transformation (change) and improvement of land legal relations in accordance with the modern needs of the development of society and the state, the provision of land interests and human and civil rights of Ukraine, the state and legal persons" (Andreitsev, 2007). At the same time, as in 2006 Prof. Volodymyr Nosik writes in a monograph entitled "Ownership of the land of the Ukrainian nation", "during 15 years Ukraine <...> has been trying, without leading to a logical conclusion, to implement at least four models of land and agrarian reforms in practice, different in directions, consequences, methods, structure, legal forms, which either contradicted each other by virtue of its principles regarding the right to land ownership and land use, or proposed new directions of land reform crossed out the reforms that had been initiated before" (Nosik, 2006).

Among the regulatory legal acts of the Ukrainian land legislation, which not only regulate certain social relations but also fix the state and determine the tendencies of development of these relations, it worth emphasizing the Resolution of the Cabinet of Ministers of Ukraine dated June 7, 2017 No. 413 "Some Issues of Improvement of Management in the Field of Use and Protection of Agricultural Lands of State Ownership and Disposal". This document, in particular, points that "state land policy can be considered as such that is in the stage of formation and doesn't meet European and world criteria and requirements for proper land resources management in full measure" (the Resolution of the Cabinet of Ministers of Ukraine, 2017). The mentioned statutory regulation, firstly, states the existence of unresolved problems in the investigated area and the need to find new approaches to their solution, and secondly, establishes a clear link between such categories as "state land policy", "land reform" and "public administration in the land sphere".

The Constitution of Ukraine declares in Arts. 13, 14 that land is the main national wealth, which is under the special protection of the state, and consolidates the foundations of the legal relationship of land ownership. Art. 16 of the Fundamental Law places obligations to ensure environmental safety and maintain ecological balance in its territory on the Ukrainian state (the Constitution of Ukraine, 1996). In order to realize these strategic tasks, it is necessary to formulate and consistently implement the state land policy as an ideological and organizational basis for the development of the relevant branch of law.

The current legislation of Ukraine doesn't have definitions for "state land policy" or "land policy", as well as a normative consolidation of the concept of "legal policy”. At the same time, these categories are rather actively used in regulatory legal acts, not to mention theoretical studies where they are paid a considerable attention both on the part of lawyers-scholars and political scientists, economists, and representatives of other sciences. We note that the use of concepts of "land policy" and "land law" as synonyms may look controversially. However, in view of the lack of wellestablished definitions and approaches to understanding legal policy and its relationship with other types of state policy, in our opinion, it can be considered acceptable as the state policy in the field of land use and protection, both at the stage of development and at the stage of implementation, is strictly bound and regulated by legal instruments. As Valentyna Minieieva noted in the dissertation study, those types of state policy (constitutional, financial, environmental, etc.), which are realized through the action of law, are varieties of legal policy (Mineeva, 2004).

\section{Legal frameworks of the establishment of state land policy}

The background of the state policy of Ukraine is laid down in the Law of Ukraine dated July 1, 2010 No. 2411-VI "On Principles of Domestic and External Policies" (hereinafter referred to as the Law on Principles of Policy). Art. 9 of this legislative domestic policy in the environmental field includes such key vectors as, among other things, the provision of citizens' constitutional rights to a safe environment, the creation of environmentally and technologically safe living conditions of the population, preservation of the natural environment, improvement of the national environmental policy, introduction of a system of ecologically balanced use of natural resources (the Law of Ukraine, 2010). By the way, it seems somewhat controversial and tautological in the context of the above-mentioned correlation between the concepts of "internal policy in the environmental field" and "national environmental policy". Such a sufficiently free manipulation by the terms without a clear definition of their content and correlation between them, in our opinion, indicates a certain declarative character of the relevant legislative provisions and their interpretation rather as political and legal slogans but not filled with the real legal content of the rules.

The next important step in our study is to establish a correlation between the state's environmental policy and its land policy. The generally accepted assertion is that in the system of social relations, the land is "characterized by multidimensionality of performed functions." In addition to the function of property, <...> land is used as a means of agrarian and agricultural production, a spatial basis for the resettlement of people, the placement of production, transport, and other infrastructure, which is necessary for the life activity of modern society, its cultural and spiritual values" (Semchyk, Kulynych, Yermolenko, and others, 2013). So, “There are many intricate and complex linkages between the economy, the social sphere and the environment, in which land use and space usually act as the vehicles for transmitting externalities" (Beinat, Nijkamp, 1998). 
Based on the foregoing, we can conclude that the state land policy, besides the environmental component, should have commercial (economic) and social one. Among the fundamentals of domestic economic policy, enshrined in Art. 7 of the Law on Policy Principles, it is worth mentioning those that directly or indirectly relate to the land sphere, namely: ensuring the competitiveness of the national economy, achieving its high growth rates, guaranteeing the state of inviolability of all forms of ownership as the basis of a market economy system, creating favourable conditions for the development of entrepreneurship, creation of conditions for the revival of the Ukrainian village, efficient use of agricultural lands, the formation of a competitive agro-industrial sector, increase of its export potential, guarantee of food security of the state, ensuring a high level of quality of agricultural products and foodstuffs, the development of a transparent market for such products, the formation of land market infrastructure, ensuring the registration of land title documents, the development of transport infrastructure, improving the efficiency of use of transit potential of the state (the Law of Ukraine, 2010).

In its turn, Art. 8 of the Law on the Principles of Policy determines priorities in the social sphere, among which there are such important land-law issues as follows: ensuring the rights and freedoms guaranteed by the Constitution of Ukraine on the basis of the introduction of European standards of social protection, the achievement of effective demographic development, the elimination of poverty, and the reduction of social stratification (the Law of Ukraine, 2010).

In terms of the basics of the state land policy, the Law of Ukraine dated June 21, 2018 No. 2469-VIII "On National Security of Ukraine" (hereinafter referred to as the Law on National Security) cannot be ignored as it is stated in p. 4 Art. 3 of this act, "state policy in the fields of national security and defence is aimed at ensuring military, foreign policy, state, economic, information, ecological safety, and cybersecurity of Ukraine, etc." (the Law of Ukraine, 2018). It seems clear that the formation and implementation of state land policy should be carried out through the prism of ensuring the fundamental national interests of Ukraine, the Law on National Security refers to them, in particular, its integration into the European political, economic, security, legal space, membership in the European Union and North Atlantic Treaty Organisation, sustainable development of the national economy, civil society and the state to secure the growth of the level and quality of life of the population (the Law of Ukraine, 2018).

It is worth emphasizing the use of the category of "sustainable development", as the Concept of Sustainable Development is the dominant methodological platform in recent decades in the whole world and in Ukraine, in particular, and due to which the entire diversity of human activity in relation to nature is developed. Studying the economic problems of land use management, Roman
Kuryltsiv, rightly emphasizes that "the achievement of sustainable development should be considered as a mandatory, logically inevitable stage of improving the methods of resource management in an environment where there is an increased demand for them requiring a reorientation of institutional and managerial processes for its achievement” (Kuryltsiv, 2017).

\section{State target programs as an economic and legal instrument of public administration in the land sector}

State target programs, which should be the result of a comprehensive and well-balanced state forecasting activity, take a key place in the system of economic and legal tools used in developing and implementing state policy. According to Art. 1 of the Law of Ukraine dated March 23, 2000 No. 1602-III “On State Forecast and Development of Programs of Economic and Social Development of Ukraine", this forecast is defined as "scientifically grounded prediction of the directions of country's development, separate branches of the economy or separate administrativeterritorial units, the possible state of economy and social field in the future, as well as alternative ways and terms for achieving the parameters of economic and social development" (the Law of Ukraine, 2000). Whereas, according to Art. 4 of the aforementioned law, the system of forecast and program documents of economic and social development includes, in particular, national programs of economic, social development, other state target programs (the Law of Ukraine, 2000). The foundations for the development of the abovementioned programs are directly laid down in the Law of Ukraine dated March 18, 2004 No. 1621-IV “On State Target Programs”, Art. 1 of which formulates their concept as "a complex of interrelated tasks and activities aimed at solving the most important problems of the development of the state, certain branches of the economy or administrative-territorial units, and are carried out using the funds of the State Budget of Ukraine and agreed according to deadlines of execution, the composition of performers, resources provision" (the Law of Ukraine, 2004).

We note that state regulation of the economy, social sphere, and natural resources use is an integral attribute of the developed countries of the world. As Marta Lesiv says "the EU directs significant efforts to support agriculture, increase its efficiency and satisfy the needs of the rural population, and encourage nonagricultural activities in a village that can provide additional income for the peasants. All this is carried out within the framework of the implementation of the EU Rural Development Policy in conjunction with other initiatives aimed at the revival and support of the village, the preservation of its authentic traditions and identity" (Lesiv, 2015). 
4. Problems of institutional provision of public administration in the field of land use and protection

Consequently, we considered the legislative acts that formed the general principles of state policy of Ukraine, in particular, environmental and land. Turning to the industry level, in the first place, it is necessary to refer to the provisions of the Law of Ukraine dated December 21, 2010 No. 2818-VI "On the Main Principles (Strategy) of the State Environmental Policy of Ukraine till 2020" (hereinafter referred to as the Strategy). Among the prime causes of environmental problems in Ukraine, this normative document marks the existing system of public administration in the field of environmental protection, the regulation of the use of natural resources, the lack of a clear separation of environmental and economic functions (the Law of Ukraine, 2010). Therefore, Goal 4 of the Strategy, which is to integrate environmental policy and improve the system of integrated environmental management, seems quite logical and top. And its practical implementation is another matter.

Let's consider this through the example of a task provided by the Strategy as "institutional development and enhancing the effectiveness of public administration in the environmental sector," and we will choose the field of control and supervision. The choice of the latter one, in our opinion, is interesting from the scientific and practical-applied point of view because one of the main vectors of the modernization of public administration, which was consolidated in the Activities Program of the Cabinet of Ministers of Ukraine approved by the Resolution of the Verkhovna Rada of Ukraine dated December 11, 2014. No. 26-VIII is the formation and implementation of a new public administration policy, which should foresee, in particular, the introduction of a regulatory model that includes the number and functions of supervisory bodies in accordance with the EU standards and the Ukraine-European Union Association Agreement (the Resolution of the Verkhovna Rada, 2014).

Consequently, in December 2002, the State Inspection for the Control of Land Use and Protection (Derzhzeminspektsiia) was created as a governmental body of state administration as a part of the State Committee for Land Resources of Ukraine. The State Inspection for the Control of Land Use and Protection was tasked with organization and implementation of state control over compliance with the requirements of land legislation by all subjects, adherence to the established procedure for acquiring and realizing the right to land, use of land parcels in accordance with the intended purpose, maintaining state recording and land registration, the reliability of information on the availability and use ofland, distribution, design, construction, and commissioning of objects that negatively affect or may affect the state of land, implementation of measures to secure land from water and wind erosion and so on (the Resolution of the
Verkhovna Rada, 2002). The purpose of the State Land Inspection, as noted in the Decree of the President of Ukraine dated August 19, 2002, No. 720, was to increase the efficiency of state land management, improve control over their use and protection (the Decree of the President of Ukraine, 2002). At the same time, in August 2009, the State Land Inspection as a separate executive body was closed down (the Resolution of the Cabinet of Ministers of Ukraine, 2009) although in June 2010 it was restored with certain peculiarities in the previous format (the Resolution of the Cabinet of Ministers of Ukraine, 2010). However, in November of the same year, this inspection was finally eliminated (the Resolution of the Cabinet of Ministers of Ukraine, 2010).

Besides, during this short period of time, the State Land Committee was abolished, and the State Agency of Land Resources of Ukraine appeared in the state system of central executive authorities.

At the beginning of September 2014, the State Ecological Inspection of Ukraine (Derzhekoinspektsiia), the State Agriculture Inspectorate of Ukraine (Derzhsilhospinspektsiia, it has received relevant powers of State Ecological Inspection since the moment of establishment), and the State Agency of Land Resources of Ukraine represented the main subjects of the land control. In addition, the Resolution of the Cabinet of Ministers of Ukraine dated September 10, 2014, No. 442 "On Optimization of the System of Central Executive Bodies" abolished the State Agricultural Inspectorate of Ukraine (but de facto, the liquidation process was prolonged for years), and functions for the implementation of state supervision (control) in part of compliance with land legislation, the use and protection of lands of all categories and forms of ownership, soil fertility were devolved on the State Ecological Inspection (the Resolution of the Cabinet of Ministers of Ukraine, 2014). There was the merger of the main supervisory powers of the land sector in the State Ecological Inspection of Ukraine, however, it was short-lived as the Government Resolution dated July 22, 2016 No. 482 "On Amendments to Certain Other Resolutions of the Cabinet of Ministers of Ukraine" as the above powers were devolved to the State Service of Ukraine for Geodesy, Cartography and Cadastre (Derzhheokadastru) (the Cabinet of Ministers of Ukraine, 2016).

In the context of the foregoing, it seems good the statement in the Policy Brief "Proper Environmental Governance in the Eastern Partnership Countries: a good deal of work outstanding", prepared by Ukrainian and foreign experts, that administrative reforms in these countries weakened the institutional structure in the field of environmental protection in some parts, and the emphasis on the need to ensure that the deregulation under these reforms does not lead to an increase in the risks to the environment (Policy Brief ). In our opinion, long-term reform processes in the executive branch 
of the state do not allow achieving integrated unity of the legal, institutional, functional, and economic subsystems in the mechanism of public environmental management, in particular, land management, the formation of which determines the level of efficiency and effectiveness of such mechanism as integrity, the importance and the need of which were noted by Prof. Vasyl Kostytskyi (Kostytskyi, 2004).

\section{Conclusions}

As a result of the study, we note that, in general, sufficient legal principles were formed in Ukrainian legislation for the development of a balanced and consistent state land policy. At the same time, the normative consolidation of the content of this policy is fragmentary. It requires the concentration of efforts of the state, public institutions, business structures, scientific and expert groups in order to develop an integrated normative legal act that should consolidate key aspects of state policy in the land sector, tools and stages of its implementation, monitoring and control, in particular, public. Public administration in relation to land resources is an area which, on the one hand, depends directly on the principles enshrined in the state land policy, on the other hand, is subjected to existing approaches to the development of a system of executive branch authorities in the state that are not characterized by stability, which negatively affects the current course of land reform in the country, the state of land resources and the environment in general. The analysis of the institutional support of control and supervisory activities in the land sector provides grounds to argue that this activity should be considered as an important element of the organizational and legal mechanism for ensuring sustainable development, and the reform of the system of the relevant authorities should not lead to weakening the potential of this important function of public administration.

\section{References:}

On the Main Directions of Land Reform in Ukraine for 2001-2005: the Decree of the President of Ukraine dated May 30, 2001, No. 372/2001. Retrieved from: http://zakon3.rada.gov.ua/laws/show/372/2001

Andreitsev V.I. (2007). Zemelne pravo i zakonodavstvo suverennoi Ukrainy: Aktualni problemy praktychnoi teorii : monohrafiia. 2-he vyd., vypr. [Land law and legislation of sovereign Ukraine: Actual problems of practical theory: monograph. 2-nd revised ed.]. Kyiv: Znannia. (in Ukrainian)

Nosik V.V. (2006). Pravo vlasnosti na zemliu Ukrainskoho narodu: monohrafiia. [Property right to land of the Ukrainian people: monograph]. Kyiv: Yurinkom Inter. (in Ukrainian)

Some Issues of Improvement of Management in the Field of Use and Protection of Agricultural Lands of State Ownership and Disposal: the Resolution of the Cabinet of Ministers of Ukraine dated June 7, 2017 No. 413. Retrieved from: http://zakon2.rada.gov.ua/laws/show/413-2017

The Constitution of Ukraine dated 28.06.1996. Retrieved from: http://zakon2.rada.gov.ua/laws/show/ 254\%D0\%BA/96-\%D0\%B2\%D1\%80

Mineeva V.I. (2004). Pravovaya politika rossiyskogo gosudarstva v oblasti ekologii: problemy realizatsii [Legal policy of Russian state in the ecology field: problems of implementation] (PhD Thesis), Stavropol: North-Caucasus Federal University.

On Principles of Domestic and External Policies: the Law of Ukraine dated July 1, 2010 No. 2411-VI. Retrieved from: http://zakon2.rada.gov.ua/laws/show/2411-17

Semchyk V.I., Kulynych P.F., Yermolenko V.M. [and others] (2013). Problemy rozvytku ahrarnoho ta zemelnoho prava Ukrainy: monohrafiia [Problems of the development of agrarian and land law of Ukraine]. Kharkiv: Pravo. (in Ukrainian)

BeinatE., Nijkamp P. (eds.) (1998). Multicriteria Analysis for Land-Use Management. Netherlands: Springer. (in English) On National Security of Ukraine: the Law of Ukraine dated June 21, 2018 No. 2469-VIII. Retrieved from: http://zakon2.rada.gov.ua/laws/show/2469-19

Kuryltsiv R.M. (2017). Intehrovane upravlinnia zemlekorystuvanniam v konteksti staloho rozvytku: teoriia, metodolohiia, praktyka [Integrated land use management in the context of sustainable development: theory, methodology, practice] (Dr. Thesis), Kyiv, National University of Life and Environmental Sciences of Ukraine.

On State Forecast and Development of Programs of Economic and Social Development of Ukraine: the Law of Ukraine dated March 23, 2000 No. 1602-III. Retrieved from: http://zakon0.rada.gov.ua/laws/show/1602-14

On State Target Programs: the Law of Ukraine dated 18.03.2004 № 1621-IV. Retrieved from: http:// zakon0.rada.gov.ua/laws/show/1621-15

Lesiv M.M. (2015). Orhanizatsiino-ekonomichni mekhanizmy zabezpechennia rozvytku silskykh terytorii krainchleniv Yevropeiskoho Soiuzu [Organizational and economic mechanisms for the development of rural Areas of the member states of the European Union], Lviv.

On the Main Principles (Strategy) of the State Environmental Policy of Ukraine till 2020: the Law of Ukraine dated December 21, 2010 No. 2818-VI. Retrieved from: http://zakon0.rada.gov.ua/laws/show/2818-17

On Activities Program of the Cabinet of Ministers of Ukraine: the Resolution of the Verkhovna Rada of Ukraine dated December 11, 2014 No. 26-VIII. Retrieved from: http://zakon2.rada.gov.ua/laws/show/26-19 
On Establishment of the State Land Inspection: the Resolution of the Verkhovna Rada of Ukraine dated 25.12.2002 No. 1958. Retrieved from: http://zakon5.rada.gov.ua/laws/show/1958-2002--\%D0\%BF

On Improvement of the System of State Land Management and Control over their Use and Protection: the Decree of the President of Ukraine dated 19.08.2002 No. 720. Retrieved from: http://zakon5.rada.gov.ua/ laws/show/720/2002

On Additional Measures for Regulation of Land Relations: the Resolution of the Cabinet of Ministers of Ukraine dated 26.08.2009 No. 901. Retrieved from: http://zakon3.rada.gov.ua/laws/show/901-2009-\%D0\%BF

On Establishment of State Inspection for the Control over Land Use and Protection: the Resolution of the Cabinet of Ministers of Ukraine dated 21.06.2010 No. 477. Retrieved from: http://zakon5.rada.gov.ua/laws/show/4772010--\%D0\%BF

On Liquidation of the State Inspection for the Control over Land Use and Protection: the Resolution of the Cabinet of Ministers of Ukraine dated 22.11.2010 No. 1068. Retrieved from: http://zakon2.rada.gov.ua/laws/show/10682010-\%D0\%BF

On Optimization of the System of Central Executive Bodies: the Resolution of the Cabinet of Ministers of Ukraine dated 10.09.2014 No. 442. Retrieved from: http://zakon2.rada.gov.ua/laws/show/442-2014-\%D0\%BF

On Amendments to Certain Other Resolutions of the Cabinet of Ministers of Ukraine: the Resolution of the Cabinet of Ministers of Ukraine dated 22.07.2016 No. 482. Retrieved from: http://zakon3.rada.gov.ua/laws/ show/482-2016-\%D0\%BF

Proper Environmental Governance in the Eastern Partnership Countries: a good deal of work outstanding: the Policy Brief. Retrieved from: http://web.archive.org/web/20131113111835/http://www.irf.ua/files/ukr/ programs/euro/toloka_env_gov.pdf

Kostytskyi V.V. (2004). Ekonomiko-pravovyi mekhanizm okhorony navkolyshnoho pryrodnoho seredovyshcha: teoriia ta praktyka [Economic and legal mechanism of environmental protection: theory and practice], Kyiv, Koretsky Institute of State and Law of National Academy of Sciences of Ukraine. 